\title{
Disposition of the Insane Defendant after Acquittal--The Long Road from Commitment to Release
}

\section{Citation}

Robert Greenwald, Disposition of the Insane Defendant after Acquittal--The Long Road from Commitment to Release, 59 J. Crim. L. \& Criminology 583 (1969).

\section{Published Version}

http://scholarlycommons.law.northwestern.edu/jclc/vol59/iss4/11/

\section{Permanent link}

http://nrs.harvard.edu/urn-3:HUL.InstRepos:12964427

\section{Terms of Use}

This article was downloaded from Harvard University's DASH repository, and is made available under the terms and conditions applicable to Other Posted Material, as set forth at http:// nrs.harvard.edu/urn-3:HUL.InstRepos:dash.current.terms-of-use\#LAA

\section{Share Your Story}

The Harvard community has made this article openly available. Please share how this access benefits you. Submit a story.

Accessibility 


\section{Journal of Criminal Law and Criminology}

Volume 59| Issue 4

Article 11

1969

\section{Disposition of the Insane Defendant after Acquittal--The Long Road from Commitment to Release}

Robert Greenwald

Follow this and additional works at: http://scholarlycommons.law.northwestern.edu/jclc

Part of the Criminal Law Commons, Criminology Commons, and the Criminology and Criminal Justice Commons

\section{Recommended Citation}

Robert Greenwald, Disposition of the Insane Defendant after Acquittal--The Long Road from Commitment to Release, 59 J. Crim. L. Criminology \& Police Sci. 583 (1968)

This Article is brought to you for free and open access by Northwestern University School of Law Scholarly Commons. It has been accepted for inclusion in Journal of Criminal Law and Criminology by an authorized administrator of Northwestern University School of Law Scholarly Commons. 


\title{
DISPOSITION OF THE INSANE DEFENDANT AFTER “ACQUITTAL"-THE LONG ROAD FROM COMMITMENT TO RELEASE
}

\author{
ROBERT GREENWALD
}

This comment traces the legal accommodations made for disposition of the insane defendant after his acquittal by reason of insanity. The main emphasis will be on the competing policies of public safety and treatment of the "patient," and how these conflicting purposes hamper the insane defendant's chances for a timely release. A growing disenchantment with the insanity "defense" itself can be traced, in part, to the haunting spectre of indeterminate detention.

Criminal defendants who are acquitted on the grounds of insanity ${ }^{1}$ are nearly always committed to mental institutions. At common law, the courts possessed the power to order immediate confinement, and many defendants were sent to jail. ${ }^{2}$ The common law has been superseded in almost all jurisdictions by statutes which provide for the defendant's civil commitment as an insane person. ${ }^{3}$

A finding of insanity at the time of the offense, "relieves the offending actor of criminal responsibility." "This means that "insanity" is a defense to the crime even though the material elements of the offense have been established. ${ }^{5}$ However, un-

1 "Insanity" is now considered a legal concept, not a medical diagnosis. Overhorser, THE PSYchiatrist AND THE LAW 61 (1953); Dession, The Mentally Ill Offender in Federal Criminal Law and Administration, 53 Y ALE L. J. 684, 686 (1944). The ambiguity between its consideration as a medical term and a legal concept has created demands for the term's abandonment. See e.g., WemoFen, MeNTaI Disorder as a CRTMTAL DEFENSE 5 (1954).

${ }^{2}$ See United States v. Lawrence, 4 Cranch C.C. 518, 26 Fed. Cas. No. 15, 577 (1835); Commonwealth v. Meriam, 7 Mass. 168 (1810).

3 Tennessee and the federal government have no legislation to deal with a jury acquittal by reason of insanity. See the statutory summary in Lynch v. Overholser, 369 U.S. 724f. (1962) (concurring opinion by Clark, J.). See generally Note, Compulsory Commitment Following a Successful Insanily Defense, 56 N.W.U.L.Rev. 409 (1961); A.L.I., Moder PENAI CoDE \& 4.03 (Proposed Official Draft, 1962); Annot., 95 A.L.R.2d 54 (1964). See also Note, Federal Commit ment of Defendants Found Not Guilty By Reason of Insanity-Proposed Legislation, 52 IowA L. REv. 930 (1967) for a recent discussion of proposals for giving federal courts statutory authority in this area.

'Daniel M'Naghten's Case, 4 St.Tr.N.S. 847, 8 Eng. Rep. 718 (H.L. 1843). See generally, DonNEILY, Golosien, \& Schwartz, Crminal Law 733-844 (1962).

6 "Insanity is a defense to be asserted at the trial as any other defense, ..." People v. Heirens, 4 III.2d like defenses such as self-defense and entrapment, which define exceptions to criminal liability, the defense of insanity "defines for confinement an exception from among those who would be free of liability." 6 Criminal processes have used the insanity defense to sanction" the "insane" who would be excluded from liability by application of general principles of criminal law. ${ }^{8}$ Insanity has therefore become a defense in name only. In virtually every state, a successful insanity defense does not bring freedom with it but triggers potentially indeterminate detention.

Post-trial commitment procedures, whether mandatory ${ }^{9}$ or discretionary, ${ }^{10}$ are premised on

131, 142, 122 N.E. 2d 231, 238 (1954). But see the acknowledgement, either intentionally or mistakenly, that insanity is evidence for determining a material element of each offense, in United States v. Currens, 290 F.2d 751, 761 (3rd Cir. 1961) and Tatum v. United States, 190 F.2d 615 (D.C. Cir. 1951). See generally, Goldstein and Katz, Abolish the Insanity Defentse-Why Not?, 72 Yane L.J. 853 (1963).

${ }^{6}$ Goldstein and Katz, supra note 5, at 855. Consider the near acknowledgement of this purpose in United States v. Currens, 290 F.2d at 767 (1961): "The throwing of the mentally ill individual from the jail back into the community, untreated and uncured, presents a great and immediate danger." See also Sminng, Mental Incapacity in CRminnal Law 2 (1961).

$7 \mathrm{By}$ "sanction" is meant any disposition of the defendant which deprives the defendant of his freedom involuntarily.

8 The function of the defense is not to absolve of criminal responsibility 'sick' persons who would otherwise be subject to criminal sanction but to authorize the state to hold those found not to possess the mens rea necessary for criminal liability.

9 E.g., Colo. Rev. STat. Ann. \& 39-8-4 (Supp. 1957); Ga. Code Ann. \$27-503 (1953); Kan. Gen.Stat.Ann. $\S 62-1532$ (1949); MASS. ANN. LAWS ch.123, \& 101 (1957); Manne PUB. L., ch. 310 (1961): Mich. STat. AnN. § 28.933(3) (1954); MINN. STAT.ANN. \& 631.19 (Supp. 1957); NeB.Rev.STAt.AnN. \$29.2203 (1943); N.Y.Sess.Laws ch.550, \& 1, 2, 3, (1960); OHIO REV. CODE \& 2945.39 (Baldwin 1953); WIS.STAT. \$ 957.11 (1955). For a complete list of the statutes and citations, see WeIHofen, Mentat Disorder as a Crmamar DefENSE 365 et seq. (1954) and references cited supra note 3 .

10 In discretionary commitment jurisdictions, the prosecutor will consider whether to begin civil commitment proceedings on the basis of a determination of present mental condition by (1) either judge or jury at the present trial; (2) by the same judge or jury at a separate hearing; (3) by a different jury or judge; (4) by a civil commitment proceeding. Note, Compulsory Commitment Following a Successful Insanity Defense, 56 N.W.U.I.REv. 409, 416 (1961). 
the assumption that a successful insanity defense has established something about the defendant which necessitates that he be kept in custody for some indefinite period. In practical terms, this implies the crime, and not merely "insanity" at the time of the act, had been proved against him. Furthermore, he is treated as if insane at the time of the trial. These assumptions pose difficult problems for legal theory. For one thing, there is usually no explicit finding by the jury that the defendant would have been guilty of the crime but for his mental condition.11 Further, since the jury's verdict is not a finding of insanity at the time of the trial $^{12}$ but only at the time of the crime ${ }^{13}$ (or, as in some jurisdictions, that there is a reasonable doubt on the question) ${ }^{14}$, the defendant is committed without a determination of his present mental condition. ${ }^{15}$

\section{JUSTIFICATIONS}

Commitment of a person acquitted by reason of insanity who may be presently sane has been justified on several grounds. One is that by pleading not guilty by reason of insanity the defendant has voluntarily accepted his commitment by raising the defense. ${ }^{16}$ This rationale forces the defendant

11 Note that the District of Columbia courts have held that an acquittal by reason of insanity carries with it the implicit finding that, the question of insanity apart, the defendant was guilty as charged. Ragsdale v. Overholser, 281 F.2d 943 (D.C. Cir. 1960).

${ }_{12}$ Accord, WeInoren, supra note 1, at 366; Note, Releasing Criminal Defendants Acquitted and Committed Because of Insanity: The Need for Balanced Administration, 68 YALE L.J. 293.

${ }_{13}$ State v. Lafosse, 142 La. 278, 76 So. 713 (1917).

14 Isaac v. United States, 284 F.2d 168 (D.C. Cir. 1960); Douglas v. United States, 239 F.2d 52 (D.C. Cir. 1956).

${ }_{15}$ There is considerable difference of opinion as to the constitutionality of statutes providing that a person acquitted by reason of his insanity at the time of the offense may be, without any further hearing on the question of his present insanity, committed to a place of confinement. The weight of authority is that such statutes do not deny to the defendant due process of law. See e.g., Ex parte Clark, 86 Kan. 539, 121 P. 492 (1912), Ex parte Slayback, $207 \mathrm{Cal}$. 480, 288 P. 769 (1930). Contra, Brown v. Urguhart, 139 F. 846 (D.C. Wash. 1905); Morgan v. State, 179 Ind. 300, 101 N.E. 6 (1913); Underwood v. People, 32 Mich. 1, 20 Am. Rep. 633 (1875). The due process arguments were recognized in Barry v. Hall, 98 F.2d 222,225 (D.C. Cir. 1938): Confinement in a mental hospital is as full and effective a deprivation of personal liberty as is confinement in jail... Due process of law does not necessarily mean a judicial proceeding-the procedure may be adopted to the nature of the case-but it does necessitate an opportunity for a hearing and a defense. See also Bauer v. Acheson, 106 F. Supp. 445,451 (D.D.C. 1952).

${ }_{16}$ Goldstein and Katz, Dangerousness and Mental Illness: Some Observations on the Decision to Release to choose between standing trial for a crime for which he cannot be punished or subjecting himself to commitment procedures. Defense counsel is then forced to compare the consequences of criminality with those of insanity in relation to length of confinement. Possibly, defense counsel would not assert the insanity defense if this would result in commitment for a wholly indeterminate time. ${ }^{17}$

A second common support for mandatory commitment rests on a presumption of continuing insanity which links the jury's verdict of insanity at the time of the offense with the mental condition of the accused at the time the court commits him. ${ }^{18}$ One justification for this presumption is that it would be "impossible to require a hearing de novo everytime that a return to sanity is claimed." 19 Moreover, the presumption is only for "continuing" insanity over a reasonable period of time ${ }^{20}$ and is rebuttable by proof that the defendant's insanity was of the sort which is unlikely to have continued. ${ }^{21}$ The burden of proof on these two issues is on the party raising them at trial.22

The most common rationale for commitment upon "acquittal" is that the insanity defense is a privilege which society awards to excuse an individual from the consequences of his criminal act. After an acquittal by reason of insanity, the offender is still regarded as mentally ill and one over whom control should be exerted for the protection of the public. This consideration allows the state

Persons Acquitted by Reason of Insanity, 70 YAIE I.J. 225, 238 (1960). People ex rel Peabody v. Chanler, 133 App. Div. 159, 162, 117 N.Y.Supp. 322, 324 (1909). Contra, In re Boyett, 136 N.C. 415,48 S.E. 789 (1904).

${ }^{77} \mathrm{See}$ discussion of possible alternatives open to defense counsel in text notes 91-102.

${ }^{18}$ In re Brown, 39 Wash. 160, 162, 81 P. 552, 554 (1905), considered such a presumption immune from constitutional attack: ... the solemn verdict of a jury after due trial establishes that he was insane when the killing occurred. The record ... shows that the character of insanity considered was not of a temporary sort... the presumption being that general insanity once shown, continues, ... the burden of proof to establish an interval rests upon the party who asserts it.

${ }_{19}$ Note, Compulsory Commitment Following a Successful Insanity Defense, 56 N.W.U.L.REv. 409, 423 (1961).

${ }^{20}$ In Hempton v. State, 111 Wis. $127,130,86$ N.W. 596,599 (1901) where two years has elapsed between the commission of the act and the raising of the presumption, the court held that the presumption "had long ceased to exist."

21 Yankulov. v. Bushong, 80 Ohio App. 497, 502, 77 N.E. $2 \mathrm{~d} 88,92$ (1945). See criticism of the presumption in State v. Pike, 49 N.H. 399, 431 (1869).

${ }_{22}^{2}$ See In re Brown, 39 Wash. 160, 81 P. 552 (1905) and supra note 18. A third justification for mandatory commitment is that the legislature might consider it appropriate to provide commitment in order to discourage false pleas of insanity. 
to commit the defendant with little or no adjudication of his present mental condition. ${ }^{23}$ However, central to this rationale, unlike that corresponding to other rationales for commitment, is treatmentnot mere confinement-for the defendant. Release will come as soon as the defendant may safely be at large. ${ }^{24}$

\section{Confinement and Treatment of the Insane Defendant After AcQuittal}

Most states provide for commitment to state hospitals or state prisons. ${ }^{25}$ As Dr. Szasz says, "Yet it is doubtful whether the distinction implicit in this terminology is anything more than an intellectual and semantic hoax. For what is a 'hospital' to which one is committed against one's will if not a "jail'?" 26 Some psychiatrists even recommend against commiting or transferring the criminally insane to hospitals because ". . the prison itself is a satisfactory place for treating most cases." 27

The latter view is challenged by some psychiatrists $^{23}$ who feel that prisons tend to ignore the psychiatric problems of the mentally ill. ${ }^{29}$ Perhaps because of these opposing views, some states have statutes providing a discretionary power in the trial judge to commit the "acquitted" defendant to either the state hospital ${ }^{30}$ or the state prison..$^{31}$

${ }^{23}$ Supra, notes 15 and 19.

24 H. R. REP. No. 892, 84th Cong., 1st Sess. 14 (1955).

${ }^{25} \mathrm{~A}$ majority of states confine the criminally insane in a separate ward or unit in the state hospital. In some states, they are kept in a ward in the penal institution. Several states have separate institutions for the "criminal insane." E.g.: Utah state prison has a mental health service unit to diagnose and treat acutely disturbed inmates. Half of the state hospitals have security "escape-proof" wards. Colorado [CoIo. REv. STAr. $\S 71-2-4$ (1953)] and Nevada [NEv.REv.STAT. $\$ 433,310$ (1958)] permit transfer of especially dangerous patients to the prison, but both states provide that the patient be visited by his psychiatrist at regular intervals. On prisons outstripping hospitals as therapeutic communities, see Diamond, Criminal Responsibility of the Mentally Ill, 14 StAN. L. REv. 59 (1961).

${ }^{26}$ Szasz, Psychiatry, Etlics and the Criminal Law, 58 CoLUM.L.REv. 183, 196 (1961).

27 Eaton, A Psychiatrist Views Rehabilitation of the Criminal Who is Mentally Ill, 4 KAN.L.REv. 356, 358 (1956).

${ }_{28}$ Satten, The Concept of Responsibility in Psychiatry and its Relationship to the Legal Problems of "Criminal Responsibility", 4 KaN. L. REv. 361, 366 (1956) see also, Magleby, Should the Criminally Insane be Housed in Prisons, 47 J. CRnM. L. C. \& P.S. 677 (1957).

${ }_{29}$ "But there has been little effort in the prisons, except in the state hospitals for the criminally insane, to utilize any of the various organic therapies that are available," Glueck, Cliange Concept in Forensic Psychiatry, 45 J. CRRT. L. C. \& P.S. 123, 132 (1954).

${ }_{30}$ The case for placing the criminally insane in hospitals rather than in prison has been most forcefully stated
The trial judge looks at the mental illness, its type, its severity, or its curability to determine the place of confinement.

Most state hospitals to which the defendant has been committed subject the patient immediately to treatment as well as observation. ${ }^{32}$ Yet all the criminally insane are not curable. Indefinite commitment for them may mean commitment for life. Public protection against the potential danger of the patient can be shaky justification for depriving

by Judge Holtzoff: To incarcerate such persons in prisons would be inhumane. Moreover, it would be unfair to other prisoners, a vast majority of whom necessarily are sane human beings. On the other hand, to turn insane criminals free would be dangerous both to the public and to themselves. For the protection of the public as well as for their own protection, they should be confined and treated in mental hospitals. In re Rosenfield, 157 F. Supp. 18, 19 (D.D.C. 1957). It is treatment and public protection-not punishment - which is desired: It is true that she is deprived of her liberty temporarily, but not every deprivation of one's liberty can be considered as an imprisonment for crime. It often becomes necessary to take into custody those who are mentally afflicted and detain them until they become no longer a menace to the public nor dangerous to themselves. Ex parte Slayback, 209 Cal. 480,490 , 288 Pac. 769,773 (1930). One court has even suggested that there exists a right to treatment. Rouse v. Cameron, 373 F.2d 451 (D.C. Cir. 1966); of. Donnell v. Cameron, 348 F.2d 64 (D.C.Cir. 1956) which suggests that commitment for four years without treatment "may be" unlawful; Sas v. Maryland, 334 F.2d 506 (4th Cir. 1964). See generally Birnbaum, The Right to Treatment, 46 A.B.A.J. 499 (1960).

${ }^{31}$ N.H.Rev.Stat. ch. 607:3 (supp. 1966); Vt.Stat. AnN. tit. 13, $\$ 4805$ (1964). These statutes allow commitment to "some suitable place." See State v. Johnson, 96 N.H. 4, 69 A.2d 515 (1949) where this power of discretion was upheld.

${ }^{32}$ See supra note 30 . A corollary to the state's providing treatment is the question of whether the patient can be forced to submit to treatment. Some doctors insist that coercion has no place in medicine: We are... primarily doctors and not jailors. We are not prepared to treat individuals, against their will, for conditions which they themselves may not want to get rid of. The authority to detain individuals indefinitely, pending their willingness to accept treatment and carry it through successfully, has not been clearly assigned to us, nor would we be eager to accept it if it were. As therapists we are not put in an untenable position if a patient is compelled by us to remain our prisoner until he accepts and successfully utilizes our therapeutic offerings. Menninger, Book Review, 38 Iowa L. REv. $697,701-702$ (1953). Others frankly admit that the "criminally insane" must be persuaded to undergo therapy: MACDONALD, PsychIATRY AND THE CRIMINAL 205 (1958); Satten, The Concept of Responsibility in Psychiatry and its Relationship to the Legal Problems of "Criminal Responsibility", 4 KaN.I.REv. 361 (1956). The statutory authority for medical treatment is not clear in all states. See e.g., ConN.Gen.Stat. § 17-194 (1958) which speaks only of transfer "... to be safely kept...", VT. STAT. ANN. tit. 13, $\$ 4803$ (1959) where the court is authorized only to commit such persons "... to be detained and observed." 
a man of liberty when it is realized that even psychiatrists have grave doubts about treatment and cure. Moreover, the need to choose between treating and curing on the one hand, and keeping the patient securely locked up on the other, inevitably detracts from the therapeutic aspect of the defendant's commitment. The measures taken to insure security are inherently inimical to treatment. The time, money, skill, and interest which could be used for rehabilitation are never fully exploited for that purpose. The mental hospital could ill afford the public alarm caused by the escape of an insane killer or rapist. The institutional commitment of the criminally insane becomes tantamount to an elaborate mask for preventive detention. ${ }^{33}$

\section{The Problem of Release}

This latter appraisal concerning the disposition of the insane defendant becomes more apparent as the accommodations made for the patient's release are viewed. Some defendants committed to mental hospitals under mandatory or discretionary commitment statutes may qualify for release almost at once. Such would be the case where the presumption of continuing insanity is rebutted by the "reasonable time" requirement. Others may enter a mental hospital for treatment and become candidates for release soon thereafter. Still others may find institutional commitment indeterminate. It is on this last group that our attention will be focused.

In general, when a person committed as insane recovers his sanity, further commitment is illegal, and he may obtain his release by habeas corpus. ${ }^{34}$ In about half the states, the power to discharge such persons is vested in the court that ordered commitment, or in some other court. ${ }^{35}$ A jury trial

${ }^{33}$ See generally Goffman, On the Characteristics of Total Institutions, in WALTER REED ARMY INSTITUTE of Research, Proceedings of the SyMpposion on Preventive ANd Social Psychiatry

${ }^{34}$ The usual provisions for release are described in Weinofen, Mental Disorder as a Crmminal DeFENSE, 376 (1954); LINDALAN AND MClNTYRE, THE MeNTally Disabled and the LaW 353 (1961). In most states, some form of court approval must be obtained. This may be preceded by a certificate from the hospital authority, or by patient's petition. A board of experts is sometimes allowed to examine the mental condition of the patient before allowing release. See also that in Michigan and Massachusetts, persons acquitted of murder by reason of insanity are committed for life subject to discharge only by the governor and a finding of nondangerousness. Mass. ANN. Laws. ch. $123 \S 101$ (1942); Mich. Cosm. LAws., $\S 766.15 \mathrm{c}$ (1948).

${ }^{35}$ The superintendent was required to give notice to "the court from which the commitment order issued" is required in some states. ${ }^{36}$ In seven states, the court may act only after the hospital authorities have certified that the person has recovered.7 A few states expressly permit the hospital authorities to discharge a person committed after acquittal without requiring any court order. ${ }^{38}$ In others the statutes are silent and it is implied that such persons may be discharged like any other patient, which will mean the hospital administrator has sole discretion. ${ }^{39}$

Even though the hospital may fail to certify that a patient has recovered, almost every jurisdiction allows the patient to initiate habeas corpus proceedings to get a court determination on his right to be discharged. (As noted above, restraint after recovery is illegal, and the patient is entitled "to sue out a writ of habeas corpus.") Ten states make the writ expressly available to persons committed after acquittal by reason of insanity, ${ }^{10}$ while several other states provide a statutory procedure which must be exhausted before the writ of habeas corpus can be used.11 Nonetheless, due process has been held to require some means for obtaining a judicial hearing on a patient's contention that he is recovered and therefore entitled to be released. A procedure that would abridge this right and leave sole discretion in the hospital authorities would be unconstitutional.42 In the majority of cases relating to the discharge of acquitted persons upon recovery, there have been specific statutory provisions like those mentioned above. The crucial issue in considering the problem of release therefore is the criteria-not the procedure-for determining "recovery" of the patient.

Great difficulty arises in determining when a

in Ex parte Boehme, 158 Tex. Crim. 278, 255 S.W.2d 206 (1952) discussed at 32 TEx. L. REv. 124 (1953).

${ }^{36}$ Illinois, Texas, and Washington.

${ }^{3 t}$ Colorado, Kentucky, Michigan, Minnesota, Texas, Washington, and West Virginia. The constitutionality of this type of provision has been upheld in several cases, see e.g., In re Clark, 86 Kan. 539, 121 P. 492 (1912); State v. Saffron, 146 Wash. 202, 262 P. 970 (1927).

«s Georgia, Kansas, Missouri, Nebraska, Oklahoma, and Virginia.

${ }^{39}$ Alabama, Arizona, Idaho, Mississippi, Montana, Nevada, North Dakota, Oregon, South Carolina, South Dakota, Tennessee, and Wyoming.

${ }^{40}$ Alabama, Iowa, Louisiana, Maryland, Michigan, Nebraska, New Jersey, North Carolina, Ohio, and Vermont.

41 In re Ostetter, 103 Kan. 487, 175 P. 377 (1918);

Thompson v. Clifford, 106 Wash. 16, 179 P. 90 (1919).

42 Underwood v. People, 32 Mich. 1 (1875); In re Boyett, 136 N.C. 415, 48 S.E. 789 (1904); Petition of Doyle, 16 R.I. 537 (1889). 
patient who has committed a criminal act has recovered sufficiently to be released:

Individuals who make good hospital patients are sometimes poor risks for release. They may become adjusted to life inside the hospital and quickly assume a fixed passive dependence. But adjustment to the hospital routine gives no assurance that they would refrain from reestablishing their undesireable behavior patterns if released. ${ }^{43}$

Moreover, the public's distaste for mistakes in this field cause hospital authorities to be very conservative in their release practices. The only reliable evidence of "cure" is the absence of observable symptoms over a long period of years. As a result, the tendency on the part of administrators is to "play it safe." Thus, those who make the final determination whether to release or detain give greater weight to nonmedical considerations than would probably be the case if noncriminal charges were involved.

The institution for confinement does not have exclusive power over the issue of release. While release is, in the first instance, a matter of medical prognosis, "the combined judgement of the court and the psychiatrists on this question is better than either standing alone and affords greater protection to the public." "Institutional release is allowed in some states, but this procedure has been objected to for several reasons. First, the belief exists that psychiatrists, faced with overcrowded facilities, will release a man sooner than he would have been released had he gone to prison. ${ }^{45}$ Second, dependent on public funds, the institutional authorities may be fearful of public reaction should they make a bad "guess" and are likely to retain a patient for a longer time than necessary. Also, many feel release should not be left solely to medicine since it is a question of responsibility and thus a matter for legal definition. ${ }^{46}$

${ }^{43}$ Weihofen, Treatment of Persons Acquitted by Insanity, 38 TEx. L. REv. 849, 864, (1960). See also Szasz, Hospilal Refusal to Release Mental Patients, 9 Creve-Mar. L. REv. 220 (1960) in which the author urges fuller recognition in release cases that the hospital play a role of protecting society against the patients; this often conflicts with their role as therapists.

${ }^{4}$ H. R. ReP. No. 892, 84th Cong, 1st Sess. 13 (1955).

${ }^{45}$ Statistics do not support this: The popular notion that the psychiatrist wishes to see the offender turned loose upon society is far from the truth; many of those who are released at the expiration of sentence he would urge as candidates for prolonged segregation. Overholser, The Place of Psychialry in the Criminal Law, 16 B.U.L. REv. 322, 326 (1936).

${ }^{15}$ One jurisdiction has abrogated its functions to
The standards set by law for determining whether or not to release the patient center on one or both of two theses: (1) whether or not the defendant has recovered his sanity, and (2) whether or not he is still a danger to himself or to others. The particular statutory formulations concerning the "sanity" theme vary. ${ }^{\text {" }}$ Some ask whether the patient is any longer mentally ill, or if the patient is cured and restored to sanity. Others ask whether he is "entirely and permanently recovered" or whether he has recovered "sufficiently ... to be released." Whatever the formulae, the statutes are usually broad enough to allow administrators to consider the problems of public safety before granting outright release. Reviewing courts have little choice but to follow the administrator's determination. The patient's real mental condition can easily be lost by the fear of potential criminality.

Other statutes do not refer to "sanity" or to the mental condition of the patient. These ask only whether continued detention is necessary for the safety of the patient or the public.ss The patient who is not dangerous is to be released, though he may be mentally ill. These jurisdictions are more concerned with preventive detention than therapeutic assistance. 49

The concept of "dangerous behavior" is ambiguous. The problem still remains of ascertaining and evaluating the process by which the crucial phrase "dangerous to himself or others" is to be given meaning. The issue arises both in hearings to review applications for release submitted by the mental hospitals, and in habeas corpus proceedings

doctors in favor of medicine and has made the issue of discharge a matter for psychiatric definition. The District of Columbia provides for release if the superintendent certifies (1) that such person has recovered his sanity (2) that, in the opinion of the superintendent, such person will not in the reasonable future be dangerous to himself or others, and (3) in the opinion of the superintendent, the person is entitled to his unconditional release ...24 D.C. CoDE ANN. \& 301 (e) (Supp. Vur, 1960). See Overholser v. Russell, 283 F.2d 195, 197 (D.C. Cir. 1960).

${ }^{47}$ See e.g., CaItF. PENAX CoDe ANN. § 1026 (1956); CONN. GEN. STAT. \$ 54-37 (1958); IND. STAT. ANN. \$ 9-1704 (1966); MICH. REV. STAT. \& 28-967 (1965Supp.); N. J. STAT. 2A: 163-3 (1953); W. VA. CODE \& 27-6-8 (1966).

${ }_{48}^{4}$ See e.g., DEx. CoDe 11- $\$ 4702$ (c) (1966 Supp.); ME. REv. STAT. ANN. 15- $\$ 104$ (1964); N.Y. CODE Crar. Proc. \& 454 (2) (3) (1966 Supp.); N.C. GEN. STAT. ANN. \& 122.86 (1950).

${ }^{49}$ See generally Goldstein and Katz, Dangerousness and Mental Illness, 70 YAIE I.J. 225 (1960); Overholser, The Present Stahus of Release of Patients from Mental Hospitals, 29 PSYchiATRIC QUARTERIX 372-80 (1955). 
in which the patient petitions for his release. It has been suggested that dangerous behavior might be construed to include:

(1) only the crime for which the insanity defense was successfully raised; (2) all crimes; (3) only felonious crimes (as opposed to misdemeanors); (4) only crimes for which a given maximum sentence or more is authorized; (5) only crimes categorized as violent; (6) only crimes categorized as violent, harmful, physical,... or irreparable to victim; (7) any conduct, even if not labelled as criminal, categorized as violent, harmful, or threatening; (8) any conduct which may produce violent retaliatory acts...; (9) any physical violence to oneself; (10) any combination of these. ${ }^{50}$

Despite the variety of possible meanings which may be given to the word "dangerous," only the Court of Appeals for the District of Columbia has addressed itself to the matter in any detail. ${ }^{51}$ Judge Fahy, concurring in Ragsdale v. Overholser, ${ }^{52}$ suggests that the question of dangerousness should turn upon the nature of the offense with which the defendant was originally charged. Under this view, continued confinement would depend on whether release posed "a danger comparable to the seriousness of the offense of which the committed person was acquitted and if that offense is of a non-violent character, a more lenient approach to the question of danger is in order." ${ }^{53}$ Judge Fahy does not address himself to the situation where the patient was originally convicted of a minor offense and is now likely to commit a more serious crime. In Overholser v. Russell, ${ }^{54}$ the court rejected Judge Fahy's suggestion:

The danger to the public need not be possible physical violence or a crime of violence. It is enough if there is competent evidence that he may commit any criminal act, for any such act will injure others and will expose the person to arrest, trial, and conviction. There is always the additional possible danger-not to be discounted even if remotethat a nonviolent criminal act may expose the perpetrator to violent retaliatory acts by the victim of the crime. ${ }^{55}$

${ }^{50}$ Goldstein and Katz, supra note 49, at 235.

51 Even the MODEI PENAI CODE, which uses the concept in its section on release, fails to define it either in its proposed statute or in the comments. A.L.I, Model Penat Code, $\$ 4.08$ (Proposed Official Draft, 1962).

52281 F.2d 943 (D.C. Cir. 1960).

${ }^{53}$ Id. at 950 .

54283 F.2d 195 (D.C. Cir. 1960).

${ }^{55}$ Id. at 198. Accord, Overholser v. O'Beirne, 302 F.2d 852 (D.C. Cir. 1962). See statements supporting
A third type of statute allows release only if the patient is both sane and not dangerous. The patient is therefore to remain in custody if he is (a) sane but dangerous or (b) insane but not dangerous. ${ }^{56}$ The wording of these statutes invites an application which conflicts with their therapeutic purpose and seems to sanction detention solely for "potential dangerousness" 37 and retribution. "A decision not to release solely on the basis of potential dangerousness would be like a decision not to discharge a tubercular patient-though no longer infectious-because he is a potential killer or check forger." ss

Finally, some states make release dependent upon proof of either sanity or lack of dangerousness. A dangerous person can compel his release, provided he is sane; an insane one may win release if he is not dangerous. ${ }^{59}$ Such statutes are based on the assumption that only patients who are both dangerous and insane should be subjected to continued confinement.

In two thirds of the states there are provisions for releasing the patient conditionally, in accordance with procedures similar to those set forth above. ${ }^{60}$ This device ${ }^{\text {il }}$ makes it unnecessary to

Judge Fahy, Judge Bazelon, concurring in Oberholser v. Russell, 283 F.2d at 199; and Judge Edgerton, dissenting in Overholser v. O'Beirne, 302 F.2d at 862.

${ }^{56}$ See e.g., WIS. STaT. \$957.11 (4) (1957); R.I. GEN. STAT. \& 26-1-7 (1956).

${ }^{57}$ See In re Williams, 157 F. Supp. 871, 876 (D.D.C. 1958) where the court specifically rejected a "potentially dangerous" test to hold patients: Many persons who are released to society upon completing the service of sentences in criminal cases are just as surely potential menaces to society as is this petitioner, ... yet the courts have no legal basis of ordering their continued confinement or mere apprehension of future unlawful acts, and must wait until another crime against society is committed or they are found insane in proper mental health proceedings before confinement may again be ordered.

${ }^{6 s}$ Goldstein and Katz, supra note 49 at 238.

${ }^{59}$ See e.g., Kans. Gen. StaT. \& 62-1532 (1949); Minn. Stat. § 631.19 (1957); VT. Stat. Ann. 13§ 4812; WASH. REv. CODE § 10.76.070 (1966 Cum. Supp.).

${ }^{60}$ See text notes 34-42.

${ }^{61}$ Also called conditional discharge, parole, furlough, leave of absence, probation or convalescent leave. Some states have provisions which expressly make such release available to patients committed after an acquittal by reason of insanity, e.g., CAIIF. WEIr. \& INST. CODE § 676Ib (1966); OHI REV. CODE ANN. § 2945.39 (1953). Most states merely extend to such patients the provisions applicable to all mental patients, e.g., KaNs. Gen. Stat. AnN. \$ 62-1532 (1949); TEx. Code Crnor. PROC. Art. 46.02 (1966). A small number of states leave the matter to the discretion of the trial judge, e.g., FLA. STAT. ANN. \& 919.11 (1960). In some states, the criminally insane are specifically barred from conditional release, e.g., CONN. GEN. STAT. § 17-198 (Supp. 1966); 
determine the "completeness" or the "permanence" of the patient's recovery from mental illness. ${ }^{62}$ Furthermore, the problems of "potential dangerousness" are provided for by the imposition of conditions on the "parolee's" freedom. ${ }^{63}$ The difficult decision to release therefore becomes less critical while the patient is also given a chance to adjust to life outside the hospital. ${ }^{64}$

The standards for conditional release are no more defined than those found for outright release. Some use "public safety" as a criterion for release. Others authorize release if the patient is "improved" or if it will serve his "best interest." 65 Whatever the standard used, conditional release is a recommended procedure for "the purpose of providing the patient with the rehabilitative support which is considered psychiatrically indicated." 66

In virtually all jurisdictions, the patient who wishes to challenge his continued detention has the burden of persuading the court that he should be released. 57 From the viewpoint of public protection, "where insanity has gone so far as actually to take human life, no sensible person will be satisfied with evidence of recovery which does not attain to the degree of reasonable certainty." 68 The ever present concern for public safety thus requires that a heavier burden-known as the "total-recovery" test-be imposed on the criminally insane to meet the standards of release than that imposed on the mentally ill patient. The "total-recovery" test is based on the theory that public protection

Ky. REv. Star. § 202.370 (1960). See also the recommendations for conditional release in the MODEL PENAL CODE, \$ 4.08.

${ }^{62}$ See text supra notes 69-78.

${ }^{63}$ E.g., California provides that the "parolees" submit themselves to regular psychiatric studies.

${ }_{64}^{64}$ It is considered therapeutically desirable for the patient to return to the community as quickly as possible in order to avoid the risks of dependence upon too protected an environment. See generally JonNT

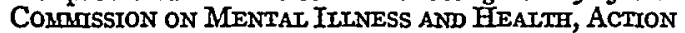
FOR MENTAI HEAITH (1961).

${ }_{65}$ Illustrative of the standards are the following: (1) Public safety-ALA. CODE \& 45-219 (1959); CArIE. WELF. \& INST. CODE \& 67\%̆b (1954); (2) ImprovedARIz. REv. Stat. ANN. \$ 36-524(A) (Supp. 1966); (3) Best interest-GA. CoDE. ANN. 88-1612(a) (1963); (4) No standard-CoLo. REv. STAT. ANN. § 39-8-4 (3) (1963). See generally IINDMAN AND MCINTYRE, THE MENTALIY DisABLED AND THE LAW 124-125, 362 (1961).

${ }_{66}$ Hough v. United States, 271 F.2d 458, 460 (D.C. Cir. 1959). Compare with the text note 43.

${ }^{67}$ Pennsylvania seems to be the only state where the burden is on those restraining the person to prove his insanity. Pa. STAT. tit. 50, \& 1482 .

${ }_{\varepsilon}$ Barry v. White, 62 App. D.C. $69,71,64$ F.2d 707, 709 (1933) quoting Thaw v. Lamb, 118 N.Y. Supp. 389, 392 (1909). must rate above the patient's chances for cure. It has been criticized for equating commitment with a prison sentence and thereby defeating "both the jury's acquittal and the medical profession's efforts at rehabilitation." 69 In the leading case which applied it, a federal district court rejected as insufficient psychiatric certification that the petitioner had "recovered sufficiently," and held that this did not comply with the statute since a sufficient recovery may be partial and not total. ${ }^{70}$ This test imposes an almost impossible question for certifying psychiatrists ${ }^{71}$ and, paradoxically, may have done the very thing the law was trying to avoid-place the ultimate determination in their hands. ${ }^{72}$

Another test, known as the "no-possibility-ofrelapse" test, poses an equally difficult task for the certifying psychiatrist ${ }^{73}$ and could mean that the patient would continue in confinement after he has recovered his sanity ${ }^{74}$ Such a test has even been

${ }^{69}$ Some courts follow the theory of imposing no heavier burden than they would upon any mentally ill patient. See In re Rosenfield, 157 F. Supp. 18 (D.D.C. 1957) where such a pronouncement was made although the patient was denied release. But see Ex parte Dubina, 311 Mich. 482, 484, 18 N.W.2d 902, 904 (1945) where a stronger showing is required as to the restoration of sanity of a person who was committed to an asylum after being acquitted in a case involving homicide than in the case of an alleged incompetent who has never been convicted or charged with a crime;" Ex parte Palmer, 26 R.I. 486, 492, 59 A. 746, 752 (1904) where because the court was charged with the high duty of protecting the public from irresponsible persons, to warrant a discharge, the petitioner must show by a clear and strong preponderance of evidence that he was not insane, a standard, it was noted, not required for the release of persons in insane asylums. See also $E x$ parte Remus, 119 Ohio St. 166, 168, 162 N.E. 740, 742 (1928) requiring "reasonable certainty that the patient's release would be without menace to the public peace." Note, 68 YALE L.J. 293, 301 (1958).

${ }^{70}$ In re Rosenfield, 157 F. Supp. 18, 21 (D.D.C. 1957).

${ }^{71}$ Indeed psychiatrists might be forced into certifying evasive reports in order to prevent continued detention and to avoid the possible psychological harm to a rehabilitated patient which the denial of a discharge might cause. Note, 68 YaIE L.J. 293, 299 (1958).

72 Consider the compromise in Minnesota where the "total recovery" test is retained but the judge is allowed some discretion. It requires that the patient be "... wholly recovered..." but provides that if he does not qualify under that standard the court may conditionally discharge him if it finds "... that no person will be endangered by his release on parole, ...., and a proper and suitable person is willing to take such committed person on parole..." MnNN. STat. ANN. $\S 631.19$ (Supp. 1966).

73 "It is not possible for a psychiatrist to certify that any patient is permanently recovered, since there is always the possibility of another psychotic reaction." Note, 68 YaLE I.J. 293, 325 (1958).

74 "He should be kept under observation in the institute for a sufficiently long period, even after a 
held to authorize the confinement of "sane persons." 75 This does not seem justified under any regular commitment statute. Under it, the patient would be unable to obtain release until capable of sustaining the extremely heavy burden of satisfying the court that even though he is "cured," there is also no possibility that he will suffer a relapse. The criminally insane patient finds himself a member of an "exceptional class" of "guilty persons" who should not go "unwhipped of justice." 76

The Court of Appeals for the District of Columbia has rendered several opinions which typify the undercurrents of suspicion and doubt running through release proceedings. Once the hospital superintendant or administrator refuses to issue a release certificate, the petitioner must persuade the court that such action was "arbitrary and capricious." The patient must show more than mere improvement. "If an abnormal mental condition renders him potentially dangerous, reasonable... doubts are to be resolved in favor of the public." 7 This requirement of "proof beyond a reasonable doubt" exists even though a mandatory commitment comes as a result not of a finding that the defendant was insane but only that there was reasonable doubt as to his sanity. ${ }^{78}$

Using the court's power to reject a petition for release as an instrument of protection is not only inconsistent with the theory that the criminally insane are not guilty of any crime, but it represents an abuse of discretion and frustrates one of the chief purposes of commitment, i.e., rehabilitation. ${ }^{79}$ Yet it has been judicially defended as a means of preventing "a plea of insanity from becoming an escape route from the consequences of a criminal conviction by substituting a short stay in

cure appears, in order to make certain that the apparent cure is not merely temporary, or as is known in psychiatry, a period of remission." In re Rosenfield, 157 F. Supp. 18, 20 (D.D.C. 1957).

${ }^{75}$ Gleason v. West Boylston, 136 Mass. 489, 491 (1884).

${ }^{76}$ Application of Perkins, 165 Cal. App. 2d 73, 76, 331 P.2d 712, 715 (1958).

7 Ragsdale v. Overholser, 281 F.2d 943, 947 (D.C. Cir. 1960); Overholser v. Lynch, 257 F.2d 667, 669-670 (D.C. Cir. 1958).

79 Orencia v. Overholser, 163 F.2d 763 (D.C. Cir. 195d); Barry v. White, 64 F.2d 707 (D.C. Cir. 1933).

7 "'The failure to grant discharge to a patient when he has recovered and it is deemed medically admissible, could quite conceivably interfere with the patient's rehabilitation." Note, supra note 73, at 299 n.32. Compare to Judge Holtzoff's statement in In re Rosenfield, 157 F. Supp. 18, 21 (D.D.C. 1957), on the purposes of commitment: "It is obvious that the Congress had a two-fold purpose: first, to protect the public; and second, to discourage unfounded pleas of insanity." a modern mental hospital for a long term of imprisonment. ..." 80

The problem raised by (1) the strict burden of proof requirement, (2) the vague statutory standards for release, and (3) the ease with which commitment of the defendant is attained, is that indeterminate commitment may in reality become preventive detention. Distrust for the insane defendant who has been acquitted tends to evoke considerations of blame and punishment rather than therapeutic concerns. The insanity defense, rather than becoming dispositive of the issues of blame and punishment, seeks to detain indefinitely for the supposed benefit of the patient and society.

The situation is posed most clearly by the person who cannot be "cured by present medical knowledge." 81 For him, acquittal by reason of insanity may bring with it a period of detention far in excess of his potential criminal sentence. This may occur because he cannot satisfy the standards for release. The rationale for such indeterminate detention is summarized in Overholser $v$. Lynch:

Frederick Lynch's confinement was not restricted to a period measured by a criminal sentence because by its very nature, hospitalization, to be effective, must be initially for an indeterminate period... and since hospitalization is remedial whereas a jail sentence is punitive. . . further consideration of the criminal penalty... becomes irrelevant, for any and all purposes.82

The heart of the problem of indeterminate detention seems to be the patient's potential dangerousness and his need for care. Detention beyond the limits fixed by the criminal code for the "crime" committed can be justified only if such detention will serve the patient's welfare (his need for care) and social welfare (protection from probable dan-

${ }^{80}$ In re Rosenfield, 157 F. Supp. 18, 20 (D.D.C. 1957).

${ }^{81}$ See Rouse v. Cameron, 373 F.2d 451 (D.C. Cir. 1966) where the court accords the detained the right to the most adequate treatment available; Birnbaum, The Right to Trealment, 46 A.B.A.J. 499 (1966); WoLFF, The Contearporary Psychotherapists Examine Themseives 15, 21, 95 (1956); Oberndorf, Unsalisfactory Results of Psychoanalytic Therapy, 19 PsycroANALYTIC Q 393 (1950).

${ }_{82}$ Overholser v. Lynch, 288 F.2d 388, 393-394 (D.C. Cir. 1961). If the detention is "therapeutic" in its objectives it is assumed it may be indefinite in duration. If punitive, it must have limits. The underlying assumption seems to be that there is no need to fear excess from a medical disposition, but only from a criminal one. 
ger). ${ }^{83}$ The welfare of the patient will be served if he will be successfully "cured." If the patient is untreatable, society can only benefit from his continued commitment. So that the "incurable" patient will not be allowed to perpetrate his act of violence on society again, the needs of the public are always raised above the rights of the patient, and indeterminable detention becomes the device for achieving this end.

At present, the law of release is filled with shortcomings. The statutory criteria usually treat all persons acquitted by reason of insanity in the same fashion. The law is aimed at detaining madmen who commit acts of outrage. Yet, the power to detain indefinitely is exercisable regardless of the type of offense originally charged and the probability of a recurrence of the offensive act. ${ }^{84}$ Furthermore, the present laws of release fail to balance, the probabilities of danger against the economic, social, and medical benefits which may result from setting the patient free..$^{35}$

Two possible solutions to the problems of indefinite detention have been suggested. ${ }^{86}$ The first would limit the offender's commitment to the maximum possible sentence he would serve if not acquitted by reason of insanity. If he is to be confined any longer it must be because he is civilly committable. The criteria for release after the maximum sentence expires become that required of all mentally ill patients. The distinction between the criminally insane and the mentally ill is not carried beyond the maximum criminal period of confinement. Society's refusal to permit release at this time would be arguably violative of due process.

The second would treat the patient as "acquitted" and-require the state to initiate civil commitment proceedings immediately. Like the first proposal, the civil commitment process becomes the means by which the rights of the patient are protected. Hopefully "dangerousness" will be defined and commitment will persist only as long as therapeutically necessary.

${ }^{83}$ See generally Waelder, Psychiatry and the Problem of Criminal Responsibility, 101 U. PA. L. REv. 378, 389 (1952).

\&4 See Note, Logical Analysis of Criminal Responsibil ity and Mandatory Commitment, 70 YAIE L.J. 1354 (1961) where the probabilities of the illegal act recurring are viewed mathematically.

${ }_{85}$ Consider in this respect the economic contribution the patient may make to society, and the social contribution to his wife and family. His release may also facilitate his cure.

${ }^{86}$ See Note, supre n.64 at 1364. See generally Morris, Impediments to Penal Reform, 33 U. CwI. L. REv. 627 (1966); Goldstein and Katz, Abolish the Insanity Defense-Why Not? 72 YALE L.J. 853, 872-876 (1963).
Civil commitment procedures do-solve some of the difficulties inherent in present indefinite detention. The detention problem is considered at a separate proceeding apart from the one which focused upon criminal responsibility. Moreover, the burden is put on the state to prove the patient will commit crimes rather than on the patient to prove he will not. In other words, the burden of proof shifts from the patient to the state to show that further detention is necessary.87

The substantive law of civil commitment, however, provides little help in solving the detention impasse, especially on the issue of "probable danger." Statutes on this point range from notion's of "mental illness" and "public danger," to whether the patient is in "need of care and treatment," or "lacks sufficient insight" to make his own decisions. Because of the complexity, of the "danger"; issue, most states have eliminated. it from their, civil commitment statutes and have substituted, the latter mentioned standards. These statutes. therefore mask the important concerns of social policy, found in the criminal setting, behind ostensibly medical judgments. ${ }^{88}$

Indeterminate detention not only threatens the liberty of the individual, but also the very existence of the defense of insanity. The possibility of $a^{\prime}$ lengthy commitment will cause many defendants and their counsel to consider the alternative criminal conviction path. At least there, suspension; parole, probationary release, or good behavior will act in a relatively precise way to cut down the sentence set by the court. The insanity defense on' the other hand carries with it the probability of a: wholly indefinite period of confinement. Furthermore, the stigmatization the defendant tries to avoid by asserting insanity is suffered as surely when committed indefinitely to a mental institution as when confined to a prison cell. ${ }^{89}$

${ }^{87}$ See generally, Kittrie, Compulsory Mental Treatment and the Requirements of 'Due Process', 21 Omro ST. L.J. 28 (1960); Ross, Commitment of the Mentally Ill, 57 Mich. L. REv. 945 (1959); Comment, Analysis of Legal and Medical Considerations in Commitment of the Mentally Ill, 56 YAIE L.J. 1178 (1947).

${ }^{88} \mathrm{See}$ a discussion of these statutes in detail in LINDman aNd McIntyre, The MENTaLIy Disabled aND THE LAW 17, 44 (1961).

${ }^{89}$ Of the total number of criminal acts committed, a relatively small proportion are detected. An even smaller proportion of offenders are formally charged with crime. Of those charged, some ninety per cent plead guilty. Only a small number of the ten per cent who stand trial plead the insanity defense. Acheson, McDonal v. United States: The Durham Rule Redefined, 51 GEO. L.J. 580 (1963); Note, Guilty Plea Bargaining, 112 U. PA. L. REv. 865 (1964). 
A lawyer will therefore avoid use of the insanity defense, with its indeterminable confinement practices, until he is able to predict with reasonable accuracy just what the prospect of release will be following its successful assertion. Until that time, the parole policy for prisoners will be favored over the release policy for the insane (except possibly in cases of extremely long criminal sentences). ${ }^{90}$

\section{Proposed Statutory Soldtion}

The following procedural guarantee would considerably improve pretrial predictability as to posttrial disposition of the insane defendant. Unfortunately, these proposals still beg the question of defining the standards for commitment and release. Development along these lines can only come through the avenue of case law. Hopefully, a procedural approach such as that suggested below will cause lawyers to move more confidently into this area.

\section{Article I: Commitment After Acquittal By Reason of Insanity}

(1) Upon acquittal by reason of insanity, the offender shall be diagnosed for the purpose of determining whether he is currently dangerous. The burden of proof on this issue shall be upon the state. If he is found to be currently dangerous, the court shall order him committed to a mental hospital. If commitment should then be ordered, the offender's period of commitment shall not exceed the outer limit of the criminal sentence which would have been imposed had he been convicted of the crime.

(2) Commitment beyond the outer period shall not be allowed unless it can be shown that it is highly probable that the offender's release would be dangerous to life or person in the reasonably near future.

(3) For the above class of offenders, the state, every ninety days, shall be required to apply to a court for renewal of the commitment. The patient shall be represented by counsel at such a hearing.

${ }^{90}$ Note also that a lawyer may take into account the therapeutic aspects of the problem such as where his client will get better treatment. See Diamond, Criminal Responsibility of the Mentally Ill, 14 STAN. L. REv. 59,85 (1961) where the author says: I do not hesitate to say that Vacaville (California correctional prison) provides a higher standard of psychiatric treatment than does the corresponding hospital for the criminally insane... operated by the Department of Mental Hygiene.

\section{Article II: Treatment of the Criminally Insane}

(1) If commitment is ordered pursuant to the preceding article, the patient shall immediately undergo treatment in an approved mental institution with medically qualified therapists.

(2) The object of such treatment shall at all times be the earliest possible release of the patient.

(3) The patient shall be allowed to petition the court at regular intervals if he believes his treatment is not following the direction of the preceding article. The burden of showing satisfactory treatment will be on the state.

\section{Article III: Conditional Release}

(1) At any time during the period of commitment, the patient, the hospital superintendent, or the court, on the advice of the board of examiners, may petition for the patient's release subject to conditions the court may deem necessary.

(2) A conditional release hearing shall be held every ninety days regardless whether such hearing is called pursuant to the preceding section. The burden of proving that the patient is eligible for such a release shall be on the patient. Such a hearing shall also provide the court with information regarding the patient's treatment and care while committed.

(3) To be eligible for conditional release, the patient need not prove total recovery. The patient must show that his conditional release will not endanger himself or those with whom he will come into contact. The patient must also show that conditional release will aid his recovery.

\section{Article IV: Unconditional Release}

(1) Unconditional release shall be ordered immediately upon the patient's serving the period for which he would have been confined by the criminal sanction attaching to his act.

(2) Beyond that period, the state must show that the patient's release would be highly dangerous to the public. The state must commence renewal proceedings immediately and provide for curative plans which must be approved by a courtappointed board.

(3) A patient who is unconditionally released from a commitment exceeding a period of one year shall appear every ninety days for one year before a court-appointed board to determine if there has been any relapse. If the patient has suffered a relapse, the state may initiate civil commitment proceedings. 
(4) At any time during the patient's commitment, the patient, the superintendent of the institution, or the court may petition for an unconditional release.91 $\mathrm{A}$ hearing shall be held and the burden of showing eligibility for release shall be placed on the patient.

\section{ALternatrve DEFENSES FOR THE INSANE DefENDaNT}

The fear of indeterminate commitment has provoked the development of alternatives to the insanity defense. If the defendant refuses to employ the insanity defense because it may result in his indeterminate detention, the conclusion would seem to be that the issue of mental illness becomes irrelevant. However, mental illness may become relevant to defenses other than insanity-defenses which provide a quite different disposition of the insane defendant than that which was outlined above.

Doctrines other than the insanity defense which offer defense counsel the opportunity to use evidence of the defendant's mental illness appear in two types of cases: (1) those in which the subjective element of intent becomes the reason for reducing the degree of guilt and the sentence following -principally cases involving the issue of premeditation; and (2) those which may lead to complete acquittal-principally cases involving specific intent, involuntary acts, and self-defense. ${ }^{92}$

Cases falling under the first category usually involve situations not quite so critical to society and in which pressure for compassion is great, such as homicides. The effort to escape capital punishment leads defendants to seek reductions from first degree murder to second degree murder or manslaughter. One doctrine, known as "partial responsibility," ${ }^{93}$ has become the focal point of these efforts.

\footnotetext{
91 See supra, note 66. See also Special Coarantree to Study Comartmagnt Procedures, Mentai IIIness and Due Process, 19-39 (1962); N.Y. Stat. ANN. 34A; $\$ 73,74,84$ (Supp. 1966); English Mental Health Act, $1959,7 \& 8$ Eliz. 2., Ch. 72 \&43. Note that psychiatry must keep pace with any proposed procedural guarantee for release. Presently, there are few successful methods of treatment and those available are very expensive. Case law will find itself hindered by the practical slowness inherent in psychiatric treatment. See generally, Symposium on the Evaluation of Therapeutic Results, 29 INTL. J. Psychoanalysts 7 (1948).

${ }^{22}$ See generally WEIHOFEN, MENTAL DISORDER AS A Crismat Defense 176 (1954).

${ }^{93}$ See generally Weihofen and Overholser, Mental Disorder Affecting The Defense of a Crime, 56 Y ALE L.J. 959 (1947).
}

The doctrine of partial responsibility had its origin in cases which admitted evidence of intoxication to negate the elements of murder.94 Today, it exists in several states to allow introduction of evidence of mental disease to prove that a defendant was incapable of the premeditation and deliberation required for first degree murder. ${ }^{95}$ In England, the doctrine known as "diminished responsibility" has been extended by statute to reduce murder to manslaughter. ${ }^{96}$ The doctrine's function is to give the jury the opportunity to find the defendant less guilty than the reasonable man and yet not force him to resort only to the insanity defense to introduce evidence of his mental illness. The defendant facing a murder charge may no longer have to choose just between, on the one hand, insanity and indeterminate commitment and, on the other, conviction and a long sentence. The choice can be enlarged to include a possible defense of diminished responsibility. This plea has become so popular that it threatens to displace the insanity defense in England.

The theory underlying the partial responsibility doctrine is that verdict and sentence should be tied more accurately than in the past to the defendant's culpability. Carried to its logical extreme, this permits the mental illness to be used generally to negate the intent element required for any crime. Such a defense is therefore potentially more than a partial defense which mitigates penalty and retains the offender in custody for a long time. The doctrine may lead to releasing the defendant entirely in cases when evidence of mental disorder is used to negate mens rea in a crime which contains no lesser offense. ${ }^{98}$ The complete acquittal of such offenders would release from

${ }^{94}$ Note, Intoxication as a Criminal Defense, 55 ColUM. L. REv. 1210, 1213 (1955).

${ }^{95}$ See supra note 5 and discussion on "insanity" as evidence. See generally Packer, Mens Rea and the SiLpreme Court, 1962 SUPREME COURT REVIEW 107; HAII, CRIMINAI LAW 72 (1965).

${ }_{96}$ The English provisions are set out in Prevenzer, The English Homicide Act, 57 Corom. L. REv. 624, 636-637 (1957). The statutory definition is such abnormality of mind (whether arising from a condition of arrested or retarded development of mind or any inherent causes or induced by disease or injury) as substantially impairs his mental responsibility.

${ }^{97}$ See Sparks, Diminished Responsibility in Theory and Practice, 27 MOD. L. REv. 9, 31-32. Under the English practice, a successful plea of diminished responsibility may lead either to a reduced sentence or to an order sending the offender to a hospital. See also Walker, Crone and Punishanent in Britain, Ch. 13 (1965).

${ }_{98}$ See supra, note 95 . 
state control the very persons society should probably most fear.

The courts have thus far been spared the complexities of the problem because the insanity defense has also been pleaded and commitment ordinarily followed. This protective device may not always be present. The state may be left entirely to the, civil commitment process to detain the offender if he is not subject to mandatory or discretionary commitment. As a result, this doctrine threatens to eliminate the insanity defense entirely for it offers the offender not only the fullest consideration of his mental illness but also the immediate prospect of freedom-at least until civil commitment proceedings are begun.

There are two other instances (besides specific intent crimes) in which traditional doctrine permits the insanity defense to be circumvented and the mentally ill offender to win complete acquittal: one is through proof that the offending act was "involuntary"; the other, in a-small number of jurisdictions, is through use of a subjective standard in the defense of self-defense. ${ }^{99}$

Crime is generally defined as a composite of two elements: a voluntary act (actus reus) and a state of mind (mens rea). This view is now codified in the Model Penal Code which defines crime as "conduct which includes a voluntary act or ... omission" and then sets out instances of behavior which are not voluntary acts: "(a) a reflex or convulsion; (b) conduct during hypnosis or resulting from hypnotic suggestion.."100 Today, it is probable that most of the conditions which have in the past supported a defense of involuntary act would also be able to support the insanity defense. The result, in practical terms, is that the mentally ill offender has still another way of placing his mental illness on the scales while at the same time minimizing the risk of commitment if he should prevail. At present, there is no pro-

99 See generally Fox, Physical Disorder, Consciousness, and Criminal Liability, 63 Colum. L. REv. 645 (1963).

${ }_{100}$ A.L.I., MODEL PENAT CODE \& 2.01 (Proposed Official Draft 1962). For commentary, see Tent. Draft No. 4, p. 119 (1955). cedure within the criminal process for retaining in custody persons acquitted because their acts were involuntary.

The law of self-defense is usually presented to the jury in two questions: (1) did the defendant in fact kill out of an honest fear of immediate danger. to himself? (2) was his belief reasonable under the circumstances? The Model Penal Code accepts the first question and its subjective standard by requiring only that the action being forced "is immediately necessary for the purpose of protecting himself." 101 Under such a formula, it is virtually inevitable that psychiatric testimony will be offered and received on the question whether the defendant was genuinely frightened and whether he used that degree of force which he believed to be "immediately necessary."

If the A.L.I. approach is adopted, its doctrine of self-defense will provide yet another avenue for the mentally ill to avoid the insanity defense and the risk of commitment it entails. In doing so, it may free persons who respond too soon to threatened danger, or who respond disproportionately.

So long as the insanity defense remains an alternative to these other defenses which the defendant may assert or not, as he wishes, it is unreasonable to expect that very many defendants will use it. It may become necessary, therefore, to develop doctrines that will once again make the insanity defense the exclusive avenue for bringing evidence of mental illness into the trial.102 Alternatively, it may be desirable to fashion commitment and release precedures, like those discussed above, for all mentally ill offenders. Neither indeterminate detention nor complete acquittal offer absolute approaches to the disposition of the criminally insane. The solution may lie in some kind of partial responsibility coupled with a statutory procedure such as that suggested.

101 A.I.I., Model PenaI Code § 304 (Proposed Oficial Draft, 1962). For commentary, see Tent. Draft No. 8 , p. 14 (1958).

102 See Wrutams, The Mental Element in Crame $111-15$ (1965). 